\title{
Does work commitment mediates the effect of Islamic work ethic on performance and turnover intention?
}

\author{
Miswanto $^{1 *}$, Rois Arifin ${ }^{2}$, Dwi Murniyati ${ }^{3}$ \\ ${ }^{1}$ Master of Management Program, STIE YKPN School of Business, Yogyakarta, Indonesia \\ ${ }^{2}$ Department of Management, Faculty of Economics and Business, Universitas Islam \\ Malang, Malang, Indonesia \\ ${ }^{3}$ Master of Management Program, STIE YKPN School of Business, Yogyakarta, Indonesia \\ *Corresponding Author(s) Email: miswanto.ykpn@gmail.com
}

\section{ABSTRACT}

Islam is a comprehensive religion that covers not only the ritual worship aspect but also ethics and acts of business. The field of Islamic work ethics has been studied by many researchers in different study settings. However, the important role of Islamic work ethics has been underexplored in work commitment studies. Therefore, this study aims to examine the direct and indirect effect of Islamic work ethics in affecting employees work performance and turnover intention through work commitment. This study used the quantitative method as their main research design. Purposive sampling was applied as a sampling technique with a five-point Likert scale of the structured questionnaire as a measurement scale and data gathering method. The bootstrap method used to test the proposed hypotheses. This study concluded that Islamic work ethic positively affects work commitment, thus work commitment positively affects work performance. This study also found that there was an insignificant effect of Islamic work ethic on work performance and turnover intention, and work commitment on turnover intention. Fundamentally, the mediation role of work commitment failed to prove in this study as there were only significant indirect effects between Islamic work ethic and work performance. In other words, the higher individual beliefs on Islamic value, the more committed employee to do their job. Thus, the more committed and enthusiastic employees on their job, the higher their work performance will be.

Keywords: Islamic Work Ethic; Work Commitment; Turnover Intention; Work Performance; Religiosity
JEL Code:

M12, M54, J24, J63

DOI:

10.31106/jema.v17i2.5533

Article History:

Received 2020/01/24

Reviewed 2020/03/30

Revised 2020/10/14

Accepted 2020/11/26

Licensed:

CC-BY 


\section{Introduction}

Islam is a comprehensive religion that covers not only the ritual worship aspect but also ethics and acts of business. Despite the negativity of Islamophobia stigma and massive prejudice that claimed Islam as an inferior also violent-prone religion, the awareness and desire in implementing Islamic values in each aspect of life is getting bigger and stronger among Muslims around the world. Zahrah et al. (2016) added that it is an obligation to Muslims to be proactive (not being lazy or being such a parasite) in providing positive contribution (good deeds) to humanity. Islam always inspires its believers to behave ethically anywhere at any time. Furthermore, compared to other work ethic endorsements like Protestant and Judaism work ethics, Islamic perspectives are considered more suitable in explaining ethics because of its comprehensiveness, moderate, and realism (Al-Aidaros \& Mohd Shamsudin, 2013; bin Salahudin et al., 2016).

Islamic work ethics is a set of moral principles that differentiates what is right from wrong that actualized as part of worship and the fulfillment of religious obligation as Muslim. Islamic work ethics has become a topic of interest of researchers in recent decades. The field of Islamic work ethics has been studied by many researchers in different study settings. Studies on Islamic work ethic were first carried out by Ali (1988) who constructed the initial scale of Islamic work ethic. Beekun (1997) broaden the study of Islamic work ethic by linking that within an organizational context. Yousef (2001) continues to explore the study by extending the role of Islamic work ethic as a moderator relationship of organizational commitment on job satisfaction. Thus, Ali \& Al-Kazemi (2007) and Khalil \& Abu-Saad (2009) strengthen the concept by adding loyalty and individualism as expected outcome behavior from Islamic work ethic. Furthermore, the studies of Islamic work ethic focus on the relationship that variable between organizational behavior like organizational citizenship and collaboration (Murtaza et al., 2016; Tufail, et al. 2017), organizational justice (Fesharaki \& Sehhat, 2018), job outcomes or performance (Hayati \& Caniago, 2012; Mohammad et al., 2018; Rawwas et al., 2018; Taufail et al., 2018; Douri et al., 2020), leadership (De Clercq et al., 2018; Patel et al., 2019) and individual behavior like innovation (Mahfoudh et al., 2016; Javed et al., 2017), motivation (Gheitani et al., 2019), professionalism (Kamarudin \& Kassim, 2020), job stress (ud Din \& Farooq, 2017), and turnover intention (Caniago \& Mustoko, 2020). However, the important role of Islamic work ethics (or ethics in general) has been underexplored in work commitment studies. Work commitment is different from organizational commitment. While work commitment is known as psychological and 
emotional linkages between employee and their job (Ramamurthi et al., 2016), organizational commitment is an employee strong beliefs toward specific organization goals and values so that they will give the best effort to maintain their membership in an organization (Al Zefeiti $\&$ Mohamad, 2017). This study aims to fill the gap in the scholarly literature by using Islamic work ethic and work commitment as an initial and mediation construct as few studies focus on the mediation role of work commitment in affecting the relationship of Islamic work ethics on work performance and turnover intention. Therefore, for instance, it can be concluded that the objective of this study was to examine the direct and indirect effect of Islamic work ethics in affecting employees' work performance and turnover intention through work commitment.

\section{Literature Review}

\section{Islamic Work Ethic, Work Commitment, Work Performance, and Turnover Intention}

In Islam, the term of ethics often refers to akhlaq which is considered as the outcome of individual beliefs about several religious values that is reflected in all spheres of life (Sehhat et al., 2015). The religious value in the Islamic perspective can be divided into several aspects including al-khayr (goodness), al-birr (righteousness), al-qist (equity), al-'adl (justice), al-haq (truth), al-ma'ruf (known), and at-taqwa (piety). On the other hand, the word of work in Islam has a noble and sincere meaning (Pardiman, 2018). Ibrahim \& Kamri (2013) stated that Muslims often view their work activity as an integral part of worship. They envision his work not only for material and physical pleasure purposes but also for engagement (at-ta'awun), worship (al-ibadah), humanity (al-ihsan), responsibilities (alamanah), self-dignity (hifz al-muru'ah), and as part of reliance towards God (at-tawakal) purpose. Work is a necessary ingredient for serving self and society (Abbasi, 2015). Ali (1988) stressed that the value of work in the Islam perspective is derived from the accompanying intentions rather than from the result of works. The Quran dictates that "Say, Undoubtedly my prayers, my sacrifice, my living, and my dying are all for Allah, the Lord of The Creation (6:162)." Although the intention is fundamental, Islam also encourages individuals to give their best effort and highly praises those who strive to live (Yousef, 2001).

The Messenger of Allah, The Prophet Mohammed, peace and blessings be upon him, said that “Don't be persistent in begging. By Allah, if one of you asks me for something and I give it to him unwillingly, then there is no blessing in what I have given him (Shahih Muslim: 1038)." He also encourages The Believers to give their best effort in everything they do, working hard then reliance on God on the result of their work. "If you were to rely upon Allah 
with the reliance. He is due, you would be given provision like the birds; They go out hungry in the morning and come back with full bellies in the evening (Sunan Ibn Majah: 4164)." Therefore, El Garah et al. (2012) concluded that Islamic work ethic can be defined as the set of moral principles based on The Quran, the sayings and practice of Prophet Mohammed that help an individual (Muslim) to distinguish between right and wrong behavior. Ibrahim \& Kamri (2013) added that Islamic work ethic is a positive action with good intentions to get Allah's blessing and to benefit society and oneself.

The field of Islamic work ethics has been studied by many researchers in different study settings. However, the important role of Islamic work ethics (or ethics in general) has been underrepresented in work commitment studies. Allah describes the characteristics of individuals who believe Islamic value as a trusted person who will keep all the promise and commitment wholeheartedly as He mentions in the Quran in Chapter 23, Verse 8, "And those who are faithfully true to their trusts (which either God or society or an individual place in their charge) and their pledges (between them and God or other persons or society)." An initial study from Harinoto et al. (2017) proves that Islamic work ethic has a positive and significant effect on work commitment. Therefore, the first hypothesis of this study can be described as follows.

$\mathrm{H}_{1}$ : There is a positive relationship between Islamic work ethic and work commitment.

Several previous studies that focus on Islamic work ethic also found that there is a significant relationship between Islamic work ethic, work performance, and turnover intention. While Hayati \& Caniago (2012), Taufail et al. (2018), Douri et al. (2020) conclude that there is a positive relationship between Islamic work ethic and work performance (which means that the higher individual beliefs on Islamic value, the higher their performance will be). Ud Din \& Farooq (2017) and Caniago \& Mustoko (2020) found the opposite relationship of Islamic work ethic on turnover intention. Generally, an individual who has higher beliefs on Islamic value tend to be more grateful for what they have and patience for what is happened as they know that the good and bad things that occur in their life are just the way of God to test their beliefs. He mentions in the Quran in Chapter 2, Verse 155-157, "And We will surely test you with something of fear and hunger and a loss of wealth and lives and fruits, but give good tidings to the patient. Who, when disaster strikes them, say, "Indeed we belong to Allah, and indeed to Him, we will return. Those are the ones upon whom are blessings from their Lord and mercy. And it is those who are the [rightly] guided." Besides, The Prophet Mohammed, peace and blessings are upon him, encourages The Believer to be optimistic in their life. He said that "Wondrous is the affair of a believer, as it is good for him 
in every matter; this is not the case for anyone but a believer. If he experiences a pleasure, he thanks Allah and it is good for him. If he experiences harm, he shows patience and it is good for him (Shahih Muslim: 2999)." Therefore, it can be concluded that the higher individual beliefs on Islamic values, the more grateful and patient they will be. Thus, the less likely they intend to leave their job or organization.

$\mathrm{H}_{2}$ : There is a positive relationship between Islamic work ethic and work performance.

$\mathrm{H}_{3}$ : There is a negative relationship between Islamic work ethic and turnover intention.

\section{Work Commitment, Work Performance, and Turnover Intention}

Work commitment is known as psychological and emotional linkages between employee and their job (Ramamurthi et al., 2016). Van Steenbergen \& Ellemers (2009) added the definition of work commitment as the degree of individual active feeling to exert their effort at work because of emotional attachment and enthusiast about the content of his or her work. There is a five universal construct of Morrow (1993) that is generally used by researchers to gain a better understanding of work commitment which is work ethic endorsement, career commitment, continuance organizational commitment, affective organizational commitment, and job involvement. While Kim et al. (2020) and Poulose \& Dhal (2020) define career commitment by the degree of motivation and psychological attachment to execute a series of the task toward one's profession, job involvement known as the degree to which a person identifies psychologically with his work (Purba et al., 2020). For instance, Tang \& Vandenberghe (2020) also describe continuance and affective organizational commitment by the need to remain as an organization member due to the cost associated with leaving and employees' emotional attachment to participate within the organization.

On the other hand, work performance defined by Al-Hawary \& Alajmi (2017) and Fogaça et al. (2018) as required employee knowledge skills, abilities, competencies, and behaviors to successfully perform tasks and meet managerial expectations by using resources available at work. In the Islamic perspective, performance is often defined by behavior rather than results as the results are the wisdom of God. He mentions in the Quran in Chapter 51, Verse 58, "Surely, it is Allah alone Who is the Great Sustainer, the Lord of immense power, the Almighty." Basu et al. (2017) and Johari \& Yahya (2016) explained that several dimensions can be considered as work performance construct which is dependability, knowledge of work, leadership qualities, quality of work, innovative, initiative, integrity, relationship, proactive, teamwork, discipline, the ability to manage, task and contextual performance. Studies from Ajayi et al. (2017), Rahiman \& Kodikal (2017) and Martini et al. 
(2020) shows that there was a positive relationship between work commitment and work performance (which means that the more commitment and enthusiast employee when executing their task, the higher the work performance will be).

$\mathrm{H}_{4}$ : Work commitment has a positive relationship with work performance.

Turnover intention is an employees' likelihood (thought or plan) to leave the existing job or organization (Fong \& Mahfar, 2013). Numerous previous studies that focus on the effect of work commitment and turnover intention show that there was a clear negative correlation between these variables. The more committed employee on their job, the less likely they intend to leave their job or organization.

$\mathrm{H}_{5}$ : Work commitment has a negative relationship with turnover intention.

\section{The Mediation Role of Work Commitment}

Few studies focus on the role of work commitment as a mediation construct in affecting the relationship of Islamic work ethics on work performance and turnover intention. An initial indication of these relationships was proposed by Harinoto et al. (2017) study which has found that work commitment effectively mediates the effect of Islamic work ethics on employee performance. Nasution \& Rafiki (2019) added that one of the work commitment constructs which is organizational commitment proves significantly mediate the relationship between Islamic work ethic and job satisfaction. Thus, the higher level of satisfaction of the employee, the higher the degree of an employee to stay with their existing job will be. Azeez et al. (2016) strengthen that work commitment also proved to have a direct effect on turnover intention even without the mediation role of job satisfaction. Therefore, the sixth and seventh hypotheses of this study can be described as follows.

$\mathrm{H}_{6}$ : The effect of Islamic work ethic on work performance is affected by work commitment.

$\mathrm{H}_{7}$ : The effect of Islamic work ethic on turnover intention is affected by work commitment.

\section{Methods}

This study used the quantitative method as their main research design. Purposive sampling was applied as a sampling technique and distributed to employees in one of the biggest steakhouse chains in Indonesia, Waroeng Steak \& Shake, through a structured questionnaire with a five-point Likert as measurement scale. Waroeng Steak \& Shake considered as the best suitable object of study for Islamic work ethic research because of the 
commitment of the owner in implementing Islamic values in their business management process. Moreover, Ar Rahmah (2017) classifies Waroeng Steak \& Shake business management process in the Good category as their vision, mission, production, distribution, the process of recruitment, and the promotional career has already follow Islamic values. The criteria sample of this study consist of employee that has more than a year of service period. The total respondent that classified to be processed in this study is 108 respondents. The detailed abstraction of the relationship between variables can be seen in Figure 1.

Figure 1. Research Framework

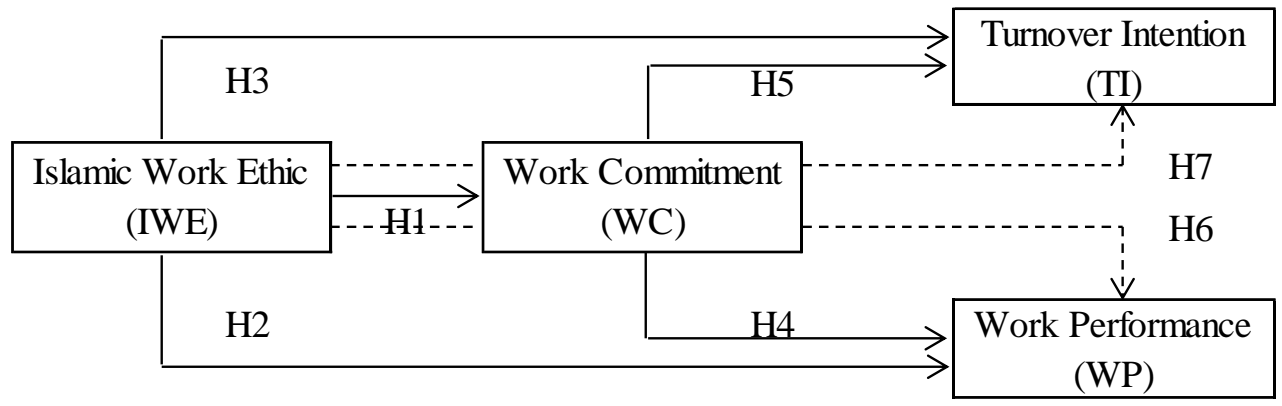

In this study, the Islamic work ethic was measure by Yousef (2001) and Ali \& Al-Kazemi (2007) dimension which consists of effort, competition, transparency, responsible conduct, hard work, trade honesty and justice, equity and fair wealth distribution in society, encouragement to skills and technological development, dedication to work, work as an obligation, and creative work result. An example of Islamic work ethic items that adopted in this study was "As an expression of my gratitude to God blessings, I always give my best effort whenever I work", "I do whatever I believe in at work, as long as it's not against God will", "I am dedicated to my work because I know that God always sees", and "For me, work is the actualization of worship". While work commitment was measure by using 7 indicators of Utami \& Bonussyeani (2009) in example "I'm emotionally attached with my current work", "I feel a sense of belonging to my current workplace", and "Whenever there were tasks that addressed to me, I'm enthusiastically working on it", work performance was measured by 9 dimensions of Wartono (2017). An example of Islamic work ethic items adopted in this study was "I was able to overcome any obstacles that happen in my work", "I meets the expected job demands", and "Indeed, I'm rarely making any mistakes". Finally, this study used the reverse of Utami \& Bonussyeani (2009) dimensions to measures turnover intention like "I am currently happy with my job because it matches with my personality and nature", "I feel excited doing my current job and intend to stay doing this job", and "I'm happy with my current job as this job offers more satisfying salary or facilities." 
Table 1. Validity and Reliability Result

\begin{tabular}{|c|c|c|c|c|c|}
\hline Variable/Item & $\begin{array}{c}\text { Pearson } \\
\text { Correlation }\end{array}$ & Criteria & $\begin{array}{c}\text { Cronbach's } \\
\text { Alpha }\end{array}$ & Criteria & Decision \\
\hline IWE & & & 0.885 & $>0.600$ & Reliable \\
\hline IWE1 & 0.686 & $>0.196$ & & & Valid \\
\hline IWE2 & 0.781 & $>0.196$ & & & Valid \\
\hline IWE3 & 0.774 & $>0.196$ & & & Valid \\
\hline IWE4 & 0.633 & $>0.196$ & & & Valid \\
\hline IWE5 & 0.672 & $>0.196$ & & & Valid \\
\hline IWE6 & 0.621 & $>0.196$ & & & Valid \\
\hline IWE7 & 0.625 & $>0.196$ & & & Valid \\
\hline IWE8 & 0.721 & $>0.196$ & & & Valid \\
\hline IWE9 & 0.666 & $>0.196$ & & & Valid \\
\hline IWE10 & 0.633 & $>0.196$ & & & Valid \\
\hline IWE11 & 0.798 & $>0.196$ & & & Valid \\
\hline WC & & & 0.768 & $>0.600$ & Reliable \\
\hline WC1 & 0.719 & $>0.196$ & & & Valid \\
\hline WC2 & 0.729 & $>0.196$ & & & Valid \\
\hline WC3 & 0.725 & $>0.196$ & & & Valid \\
\hline WC4 & 0.694 & $>0.196$ & & & Valid \\
\hline WC5 & 0.746 & $>0.196$ & & & Valid \\
\hline WC6 & 0.307 & $>0.196$ & & & Valid \\
\hline WC7 & 0.793 & $>0.196$ & & & Valid \\
\hline WP & & & 0.806 & $>0.600$ & Reliable \\
\hline WP1 & 0.519 & $>0.196$ & & & Valid \\
\hline WP2 & 0.798 & $>0.196$ & & & Valid \\
\hline WP3 & 0.790 & $>0.196$ & & & Valid \\
\hline WP4 & 0.718 & $>0.196$ & & & Valid \\
\hline WP5 & 0.675 & $>0.196$ & & & Valid \\
\hline WP6 & 0.476 & $>0.196$ & & & Valid \\
\hline WP7 & 0.594 & $>0.196$ & & & Valid \\
\hline WP8 & 0.568 & $>0.196$ & & & Valid \\
\hline WP9 & 0.545 & $>0.196$ & & & Valid \\
\hline
\end{tabular}


Table 1 Continued.

\begin{tabular}{ccccc} 
TI & & 0.842 & $>0.600$ & Reliable \\
TI1 & 0.593 & $>0.196$ & & Valid \\
TI2 & 0.737 & $>0.196$ & & Valid \\
TI3 & 0.774 & $>0.196$ & Valid \\
TI4 & 0.704 & $>0.196$ & Valid \\
TI5 & 0.709 & $>0.196$ & Valid \\
TI6 & 0.816 & $>0.196$ & Valid \\
TI7 & 0.725 & $>0.196$ & Valid \\
\hline
\end{tabular}

The bootstrap method which was developed by Preacher \& Hayes (2008) used to test the proposed hypotheses. Hadi et al. (2016) stated that the usage of Preacher \& Hayes bootstrapping (resampling) technique to test the potential direct and indirect effect between variables has an advantage over Sobel's test as this test does not rely on assumptions of normality and suitable for small sample size. Finally, to process the data into the proposed hypotheses testing, the validity and reliability measurements of research instruments need to be done. The results of the validity and reliability testing in Table 1 show that all instruments used in this study were valid and reliable.

\section{Result and Discussion}

Table 2. Demographic Profile

\begin{tabular}{lcc}
\hline Classification & Description & Percentages $(\%)$ \\
\hline \multirow{2}{*}{ Gender } & Male & 94 \\
& Female & 6 \\
Year of Birth & $1965-1979($ Generation X) & 5 \\
& $1980-2001($ Generation Y) & 94 \\
& $\geq 2002($ Generation Z) & 1 \\
Educational & Junior High School & 11 \\
Background & Senior High School & 75 \\
& Diploma & 5 \\
& Bachelor & 9 \\
\hline
\end{tabular}

The demographic profile (Table 2) shows that the majority of the respondent in this study were male who can be classified as Y generation (born 1980-2001) and having high school degree as the last educational background. The characteristics of the majority 
respondent in this study that can be categorized as Millennials (Y generation) indicates that they are adaptive, confidence, high self-esteem, assertiveness, achievement-focused, techsavvy, high expectations for advancements opportunities within their careers, and dedicated (Smith \& Nichols, 2015). Therefore, Millennials characteristics and the level of education of the majority of the respondent in this study that only holds senior high school degree may affect the relationship between variables in this study.

Table 3. Hypotheses Testing

\begin{tabular}{lccccc}
\hline Hypotheses & t-Value & $\begin{array}{c}\text { t-Table } \\
\text { Criteria }\end{array}$ & Sig. & $\begin{array}{c}\text { Sig. } \\
\text { Criteria }\end{array}$ & Decision \\
\hline $\mathrm{H}_{1}$ IWE -> WC & 8.621 & $>1.984$ & 0.000 & $<0.005$ & Accepted \\
$\mathrm{H}_{2}$ IWE -> WP & 0.705 & $>1.984$ & 0.483 & $<0.005$ & Rejected \\
$\mathrm{H}_{3}$ IWE -> TI & -1.436 & $>1.984$ & 0.155 & $<0.005$ & Rejected \\
$\mathrm{H}_{4}$ WC -> WP & 3.558 & $>1.984$ & 0.001 & $<0.005$ & Accepted \\
$\mathrm{H}_{5}$ WC -> TI & -1.064 & $>1.984$ & 0.290 & $<0.005$ & Rejected \\
\hline
\end{tabular}

Table 3 of the hypotheses testing shows that this study was only able to confirm $\mathrm{H}_{1}$ and $\mathrm{H}_{4}$, as there were significant effects of Islamic work ethic on work commitment, thus work commitment on work performance. The value of t-tested between variables was 8.621 and 3.558 (which is lower than the value of t-statistics 1.984) with a significant value of 0.000 and 0.001 (which is higher than significances criteria of 0.05). This study supports previous studies by Sappe et al. (2016), Rahiman \& Kodikal (2017) Ajayi et al. (2017) Harinoto et al. (2017), Martini et al. (2020) that found Islamic work ethic has a positive effect on work commitment, thus work commitment has a positive effect on work performance. It also supports the arguments that the higher individual beliefs on Islamic values, the more committed employee in executing their task. Thus, the more committed and enthusiastic employees on their job, the higher their work performance will be.

The result of this study also was not able to confirm $\mathrm{H}_{2}$ and $\mathrm{H}_{3}$ which stated that there is a positive relationship of Islamic work ethic on work performance and turnover intention as the value of t-tested was 0.705 and -1.436 (which is lower than the value of $t$-statistics 1.984 ) with significant value of 0.483 and 0.155 (which is higher than significances criteria of 0.05 ). This study failed to support numerous previous studies by Hayati \& Caniago (2012), ud Din \& Farooq (2017), Taufail et al. (2018), Douri et al. (2020) and Caniago \& Mustoko (2020). By definition, an Islamic work ethic can be described as individual beliefs/views about several religious values. While work performances were complex employees' behaviors to 
successfully perform tasks and meet managerial expectations. Therefore, it is understandable that there is no correlation between Islamic work ethic and work performances as there's a big difference between simply believing, having faith, and taking real action. Individually don't always behave like their beliefs. The big differences between the score of Islamic work ethic means (4.382) compared to the score of work performance means (2.965) in this study proved that arguments. Also, the natures of the majority of the respondent in this study that only hold senior high school degree affected the level of their job performance as the lower the level of education the more likely an individual is to have a poor level of knowledge, competencies, and skills (Tammaru \& Leetmaa, 2007; Nilsagård \& Lohse, 2010; van Deursen et al., 2015; Mikolajczak \& Van Bellegem, 2017; Jafari-Sadeghi et al., 2019; Cincera et al., 2020). Employees might believe that they always give their best effort in executing every task as an expression of their gratitude to God's blessings but still they often make many mistakes so that their work result is below expectation. They also might see that work is the actualization of the worship but still they were unable to overcome any obstacle that happens in their work. It has therefore been suggested employees need to enhance their commitment to Islamic values by improving their competencies and skills to meet that job demand. He mentions in the Quran in Chapter 58, Verse 11, "Allah will raise those who believe among you and those who were given knowledge, by many degrees. And Allah is All-Aware of what you do." Also, The Prophet Mohammed, peace and blessings be upon him, said that "Seeking knowledge is an obligation upon every Muslim (Sunan Ibn Majah: 224)."

Regarding the relationship of Islamic work ethics on turnover intention, the majority of the respondent in this study that categorized as the Millenials was considered as the main reason for the insignificant effect between variables. Ivanovic \& Ivancevic (2019) stated that compared to the previous generation, the level of the turnover intention of the Millenials was the largest. Siahaan \& Gatari (2020) even mentioned that the highest turnover in companies is found in the Millennials generation. The result of this study also provides an insight of the overall Muslim behavior in the workplace that although there were employees' who are having higher belief in Islamic values, whenever there are any offers that provide better salaries and facilities, challenge, and personality fits, they will rationally consider it. Resignation is not prohibited in Islam as long as it does not violate the prior agreement of each other. He mentions in the Quran in Chapter 62, Verse 10, "And when the prayer is ended, then disperse in the land and seek of Allah's bounty, and remember Allah much, that ye may prosper." Also, The Prophet Mohammed, peace and blessings be upon him, stressed 
that "Conciliation between Muslims is permissible except the conciliation which makes lawful unlawful and unlawful lawful (Sunan Abi Dawud: 3594)."

This study also failed to prove the conclusion of Azeez et al. (2016) and Hardaningtyas (2020) studies that stated work commitment has a negative relationship on turnover intention. The value of t-tested between variables was lower than the value of t-statistics $(-1.064<$ 1.984) with a significant value of 0.290 , which is higher than significances criteria of 0.05 , thus, $\mathrm{H}_{5}$ was rejected. Also, the low mean score of work commitment (2.509) compared to the score of turnover intention means (1.305) caused the insignificancy relationship between variables. Cincera et al. (2020) added that the lower the level of educational background, the higher the willingness to move to a new profession or organization.

Table 4. The Mediation Role of Work Commitment

\begin{tabular}{lccccc}
\hline Hypotheses & Effect & BootSE & BootLLCI & BootULCI & Decision \\
\hline $\mathrm{H}_{6}$ IWE -> WC -> WP & -0.095 & 0.093 & -0.278 & 0.901 & Rejected \\
$\mathrm{H}_{7}$ IWE -> WC -> TI & 0.327 & 0.110 & 0.136 & 0.572 & Rejected* \\
\hline
\end{tabular}

*) $\mathrm{H}_{7}$ was rejected due to the mediation rule by Wong (2015)

Hayes (2018) stated that when the upper and lower bounds of the 95\% confidence interval do not contain zero, it means that the indirect effect between variables was existed or significant. Wong (2015) added that the mediation effect has failed to prove whenever the direct effect between variables is not significant. Although this study successfully proves the significant effect of Islamic work ethic on work commitment, and work commitment on work performance, the mediation testing result as presented in Table 4 show that there was no significant proof of the mediation role of work commitment in affecting the relationship between Islamic work ethic and work performance as the value of BootLLCI $(-0.278)$ and BootULCI (0.901) of $\mathrm{H}_{6}$ contain zero. Therefore, this finding only revealed that there was an indirect effect between Islamic work ethic and work performance. On the other hand, although the value of BootLLCI (0.136) and BootULCI (0.572) of $\mathrm{H}_{7}$ doesn't contain zero, the hypotheses decision was still rejected because there were no significant prove on the direct relationship between Islamic work ethic and work commitment, also work commitment and turnover intention.

\section{Conclusion and Suggestion}

This study aims to examine the direct and indirect effect of Islamic work ethics in affecting employees' work performance and turnover intention through work commitment. 
This study found that Islamic work ethic positively affects work commitment, thus work commitment has a positive effect on work performance. In other words, the higher individual beliefs on Islamic values, the more committed and enthusiastic employees on their job that ended in the higher work performance result. Unlike the previous study which concluded that there is a positive relationship between Islamic work ethic on work performance and turnover intention, and work commitment negatively affects turnover intention, this study concluded the opposite. The natures of the majority of the respondent in this study that only hold senior high school degree and categorized as the Y generation (Millenials) was considered as the main reason of the insignificant effect between variables. Finally, the mediation role of work commitment failed to prove in this study. This study only found that there was an indirect effect between Islamic work ethic and work performance. Future studies should extend their theoretical scope and sample characteristics in a broader way to gain a better perspective. The usage of organizational behavior issues (like organizational citizenship and collaboration, organizational justice, job outcomes, leadership) and individual issues (like innovation, motivation, professionalism) may be considered as the extension construct of future study.

\section{References}

Abbasi, T. F. (2015). Impact of work overload on stress, job satisfaction and turnover intentions with moderating role of Islamic work ethics. Management Studies and Economic Systems, 54(2518), 1-11.

Ajayi, A., Shiyanbade, B. W., Ajayi, O. A., Olodude, D. O., \& Olowoporoku, A. J. (2017). Influence of personality traits and work commitment on job performance of public secondary school teachers in Oyo South Senatorial District. International Journal of Management, Accounting and Economics, 4(3), 200-217.

Al-Aidaros, A. H., \& Mohd. Shamsudin, F. (2013). Ethics and ethical theories from an Islamic perspective. International Journal of Islamic Thought, 4, 1-13.

Al-Hawary, S. I. S., \& Alajmi, H. M. (2017). Organizational commitment of the employees of the ports security affairs of the State of Kuwait: the impact of human recourses management practices. International Journal of Academic Research in Economics and Management Sciences, 6(1), 52-78.

Al Zefeiti, S. M. B., \& Mohamad, N. A. (2017). The Influence of organizational commitment on Omani public employees' work performance. International Review of Management and Marketing, 7(2), 151-160.

Ali, A. (1988). Scaling an Islamic work ethic. The Journal of Social Psychology, 128(5), 
575-583. https://doi.org/10.1080/00224545.1988.9922911

Ali, A. J., \& Al-Kazemi, A. A. (2007). Islamic work ethic in Kuwait. Cross Cultural Management: An International Journal, 14(2), 93-104. https://doi.org/10.1108/13527600710745714

Ar Rahmah, R. (2017). Etika dan manajemen bisnis islam (Studi kasus di warong steak and shake cabang SM Raja Medan). J-EBIS (Jurnal Ekonomi Dan Bisnis Islam), 2(2), 1-25.

Azeez, R. O., Jayeoba, F., \& Adeoye, A. O. (2016). Job satisfaction, turnover intention and organizational commitment. Journal of Management Research, 8(2), 102-114.

Basu, E., Pradhan, R. K., \& Tewari, H. R. (2017). Impact of organizational citizenship behavior on job performance in Indian healthcare industries. International Journal of Productivity and Performance Management, 66(6), 780-796. https://doi.org/10.1108/IJPPM-02-2016-0048

Beekun, R. I. (1997). Islamic business ethics. Herdon: International Institute of Islamic Thought (IIIT).

bin Salahudin, S. N., Binti Baharuddin, S. S., Abdullah, M. S., \& Osman, A. (2016). The effect of Islamic work ethics on organizational commitment. In Procedia Economics and Finance (35) (pp. 582-590).

Caniago, S. A., \& Mustoko, D. (2020). The effect of Islamic work ethics on organizational commitment, job satisfaction, and turnover intentions of Islamic microfinance in Pekalongan. International Journal of Islamic Business and Economics (IJIBEC), 4(1), 30-39. https://doi.org/https://doi.org/10.28918/ijibec.v4i1.1571

Cincera, J., Simonova, P., Kroufek, R., \& Johnson, B. (2020). Empowerment in outdoor environmental education: who shapes the programs? Environmental Education Research, 1-17. https://doi.org/10.1080/13504622.2020.1814205

De Clercq, D., Haq, I. U., Raja, U., Azeem, M. U., \& Mahmud, N. (2018). When is an Islamic work ethic more likely to spur helping behavior? The roles of despotic leadership and gender. Personnel Review, 47(3), 630-650. https://doi.org/10.1108/PR06-2017-0192

Douri, J. A. A., Aldabbagh, I., Mohammad, M. M., \& Qawasmeh, R. A. (2020). The impact of Islamic work ethics on job performance with mediating role of intrinsic motivation. Academy of Strategic Management Journal, 19(2).

El Garah, W., Beekun, R. I., Habisch, A., Lenssen, G., Adaui, C. L., Ismaeel, M., \& Blaim, K. (2012). Toward applied Islamic business ethics: responsible halal business. Journal of Management Development. 
Fesharaki, F., \& Sehhat, S. (2018). Islamic human resource management (iHRM) enhancing organizational justice and employees' commitment. Journal of Islamic Marketing, 9(1), 204-218. https://doi.org/10.1108/JIMA-03-2017-0029

Fogaça, N., Rego, M. C. B., Melo, M. C. C., Armond, L. P., \& Coelho, F. A. (2018). Job performance analysis: scientific studies in the main journals of management and psychology from 2006 to 2015. Performance Improvement Quarterly, 30(4), 231-247. https://doi.org/10.1002/piq.21248

Fong, Y. L., \& Mahfar, M. (2013). Relationship between occupational stress and turnover intention among employees in a furniture manufacturing company in Selangor. Jurnal Teknologi, 64(1), 33-39.

Gheitani, A., Imani, S., Seyyedamiri, N., \& Foroudi, P. (2019). Mediating effect of intrinsic motivation on the relationship between Islamic work ethic, job satisfaction, and organizational commitment in banking sector. International Journal of Islamic and Middle Eastern Finance and Management, 12(1), 76-95. https://doi.org/10.1108/IMEFM-01-2018-0029

Hadi, N. U., Abdullah, N., \& Sentosa, I. (2016). An easy approach to exploratory factor analysis: Marketing perspective. Journal of Educational and Social Research, 6(1), 215.

Hardaningtyas, R. T. (2020). Personal resources and turnover intention among private sector employees: Does work engagement still matter? JEMA: Jurnal Ilmiah Bidang Akuntansi Dan Manajemen, 17(1), 1. https://doi.org/10.31106/jema.v17i1.4989

Harinoto, M., Frisdiantara, C., Sanusi, A., \& Triatmanto, B. (2017). Islamic Work Performance of Muslim Employees. In Proceedings of Social Sciences, Humanities and Economics Conference (SoSHEC 2017). Paris, France: Atlantis Press. https://doi.org/10.2991/soshec-17.2018.22

Hayati, K., \& Caniago, I. (2012). Islamic work ethic: The role of intrinsic motivation, job satisfaction, organizational commitment and job performance. Procedia - Social and Behavioral Sciences, 65, 1102-1106. https://doi.org/10.1016/j.sbspro.2014.05.148

Hayes, A. F. (2018). Partial, conditional, and moderated moderated mediation: Quantification, inference, and interpretation. Communication Monographs, 85(1), 4-40. https://doi.org/10.1080/03637751.2017.1352100

Ibrahim, A., \& Kamri, N. A. (2013). Measuring the Islamic Work Ethics: An Alternative Approach. Islamic Perspective on Management: Contemporary Issue, 135-16.

Ivanovic, T., \& Ivancevic, S. (2019). Turnover intentions and job hopping among millennials in Serbia. Economies Management: Journal of Sustainable Business and Management 
Solutions in Emerging, 24(1), 53-63.

Jafari-Sadeghi, V., Kimiagari, S., \& Biancone, P. Pietro. (2019). Level of education and knowledge, foresight competency and international entrepreneurship. European Business Review, 32(1), 46-68. https://doi.org/10.1108/EBR-05-2018-0098

Javed, B., Bashir, S., Rawwas, M. Y. A., \& Arjoon, S. (2017). Islamic work ethic, innovative work behaviour, and adaptive performance: the mediating mechanism and an interacting effect. Current Issues in Tourism, 20(6), 647-663. https://doi.org/10.1080/13683500.2016.1171830

Johari, J., \& Yahya, K. K. (2016). Job characteristics, work involvement, and job performance of public servants. European Journal of Training and Development, 40(7), 554-575. https://doi.org/10.1108/EJTD-07-2015-0051

Kamarudin, A. A., \& Kassim, S. (2020). An analysis of customer satisfaction on employee professionalism: a comparison between Islamic and conventional banks in Malaysia. Journal of Islamic Marketing. https://doi.org/10.1108/JIMA-03-2020-0063

Khalil, M., \& Abu-Saad, I. (2009). Islamic work ethic among Arab college students in Israel. Cross Cultural Management: An International Journal, 16(4), 333-346. https://doi.org/10.1108/13527600911000320

Kim, S. J., Song, M., Hwang, E., Roh, T., \& Song, J. H. (2020). The mediating effect of individual regulatory focus in the relationship between career commitment and job satisfaction. European Journal of Training and Development. https://doi.org/https://doi.org/10.1108/EJTD-02-2020-0030

Mahfoudh, A., Din, M. S. H., \& Jusoh, M. S. (2016). The effect of Islamic work ethics (Akhlaq) to innovation capability. In Contemporary Issues and Development in the Global Halal Industry (pp. 381-390). Singapore: Springer Singapore. https://doi.org/10.1007/978-981-10-1452-9_35

Martini, I. A. O., Supriyadinata, A. E., Sutrisni, K. E., \& Sarmawa, I. W. G. (2020). The dimensions of competency on worker performance mediated by work commitment. Cogent Business \& Management, 7(1), 1794677.

Mikolajczak, M., \& Van Bellegem, S. (2017). Increasing emotional intelligence to decrease healthcare expenditures: How profitable would it be? Personality and Individual Differences, 116, 343-347. https://doi.org/10.1016/j.paid.2017.05.014

Mohammad, J., Quoquab, F., Idris, F., Al-Jabari, M., Hussin, N., \& Wishah, R. (2018). The relationship between Islamic work ethic and workplace outcome. Personnel Review, 47(7), 1286-1308. https://doi.org/10.1108/PR-05-2017-0138 
Morrow, P. C. (1993). The Theory and Measurement of Work Commitment. Greenwich, Connecticut: JAI Press Inc.

Murtaza, G., Abbas, M., Raja, U., Roques, O., Khalid, A., \& Mushtaq, R. (2016). Impact of Islamic work ethics on organizational citizenship behaviors and knowledge-sharing behaviors. Journal of Business Ethics, 133(2), 325-333. https://doi.org/10.1007/s10551014-2396-0

Nasution, F. N., \& Rafiki, A. (2019). Islamic work ethics, organizational commitment and job satisfaction of Islamic banks in Indonesia. RAUSP Management Journal, 55(2), 195-205. https://doi.org/10.1108/RAUSP-01-2019-0011

Nilsagård, Y., \& Lohse, G. (2010). Evidence-based physiotherapy: A survey of knowledge, behaviour, attitudes and prerequisites. Advances in Physiotherapy, 12(4), 179-186. https://doi.org/10.3109/14038196.2010.503812

Pardiman. (2018). The effect of social capital and organizational commitment toward lecturer performance with islamic work ethics as a moderating role. JEMA: Jurnal Ilmiah Bidang Akuntansi Dan Manajemen, 15(1), 12-26. https://doi.org/https://dx.doi.org/10.31106/jema.v15i01.779

Patel, T., Salih, A., \& Hamlin, R. G. (2019). Perceived managerial and leadership effectiveness in UAE and Egypt: A comparison through the combined lenses of Islamic work ethics and Islamic leadership. European Management Review, 16(3), 647-666. https://doi.org/10.1111/emre.12184

Poulose, S., \& Dhal, M. (2020). Role of perceived work-life balance between work overload and career commitment. Journal of Managerial Psychology, 35(3), 169-183. https://doi.org/10.1108/JMP-03-2018-0117

Preacher, K. J., \& Hayes, A. F. (2008). Asymptotic and resampling strategies for assessing and comparing indirect effects in multiple mediator models. Behavior Research Methods, 40(3), 879-891. https://doi.org/10.3758/BRM.40.3.879

Purba, P., Dalimunthe, R. F., \& Absah, Y. (2020). The effect of work skills and employee's job involvement on employee performance through job satisfaction in manpower office of Medan, Indonesia. European Journal of Human Resource Management Studies, 4(2).

Rahiman, M. H. U., \& Kodikal, R. (2017). Impact of employee work related attitudes on job performance. British Journal of Economics, Finance and Management Sciences, 13(2), 93-105.

Ramamurthi, K., Vakilbashi, A., Rashid, S. Z. A., Mokhber, M., \& Basiruddin, R. (2016). Impact of job stressors factors on employees' intention to leave mediated by job 
engagement and dispositional factors. International Review of Management and Marketing, 6(3), 528-531.

Rawwas, M. Y. A., Javed, B., \& Iqbal, M. N. (2018). Perception of politics and job outcomes: moderating role of Islamic work ethic. Personnel Review, 47(1), 74-94. https://doi.org/10.1108/PR-03-2016-0068

Sappe, S., Rante, Y., Tuhumena, R., \& Bharanti, B. E. (2016). Effect of leadership on employee's performance mediated by cultural organization, work commitment and motivation. Journal of Economics and Behavioral Studies, 8(2(J)), 101-107. https://doi.org/10.22610/jebs.v8i2(J). 1258

Sehhat, S., Mahmoud Zadeh, S. M., Ashena, M., \& Parsa, S. (2015). Positive psychological capital: The role of Islamic work ethics in Tehran Public Organizations. Iranian Journal of Management Studies, 8(4), 545-566. https://doi.org/https://dx.doi.org/10.22059/ijms.2015.55001

Siahaan, F. L., \& Gatari, E. (2020). Searching for meaning: The mediating role of work engagement in the relationship between meaningful work and turnover intention of Millennials. Psikohumaniora: Jurnal Penelitian Psikologi, 5(1), 15-28.

Smith, T. J., \& Nichols, T. (2015). Understanding the millennial generation. The Journal of Business Diversity, 15(1), 39-47.

Tammaru, T., \& Leetmaa, K. (2007). Suburbanisation in relation to education in the Tallinn metropolitan area. Population, Space and Place, 13(4), 279-292. https://doi.org/10.1002/psp.444

Tang, W.-G., \& Vandenberghe, C. (2020). Is affective commitment always good? A look at within-person effects on needs satisfaction and emotional exhaustion. Journal of Vocational Behavior, 119, 103411. https://doi.org/10.1016/j.jvb.2020.103411

Taufail, M., Hussain, S., \& Shahzad, K. (2018). Combined effects of job insecurity and islamic work ethics on job satisfaction and job performance. Journal Of Business \& Economics, 10(2), 1-24.

Tufail, U., Ahmad, M. S., Ramayah, T., Jan, F. A., \& Shah, I. A. (2017). Impact of Islamic work ethics on organisational citizenship behaviours among female academic staff: the mediating role of employee engagement. Applied Research in Quality of Life, 12(3), 693-717. https://doi.org/10.1007/s11482-016-9484-5

ud Din, M., \& Farooq, S. (2017). Effect of Islamic work ethics on employee well-being, job stress and turnover intention. Sarhad Journal of Management Sciences, 2(02), 157-163.

Utami, I., \& Bonussyeani, N. E. S. (2009). Pengaruh job insecurity, kepuasan kerja, dan 
komitmen organisasional terhadap keinginan berpindah kerja. Jurnal Akuntansi Dan Keuangan Indonesia, 6(1), 117-139. https://doi.org/10.21002/jaki.2009.06

van Deursen, A. J. A. M., van Dijk, J. A. G. M., \& ten Klooster, P. M. (2015). Increasing inequalities in what we do online: A longitudinal cross sectional analysis of Internet activities among the Dutch population (2010 to 2013) over gender, age, education, and income. Telematics and Informatics, 32(2), 259-272. https://doi.org/10.1016/j.tele.2014.09.003

Van Steenbergen, E. F., \& Ellemers, N. (2009). Feeling Committed to Work: How Specific Forms of Work-Commitment Predict Work Behavior and Performance Over Time. Human Performance, 22(5), 410-431. https://doi.org/10.1080/08959280903248385

Wartono, T. (2017). Pengaruh stres kerja terhadap kinerja karyawan (studi pada karyawan majalah Mother and Baby). KREATIF: Jurnal Ilmiah Prodi Manajemen Universitas Pamulang, 4(2).

Wong, K. K. (2015). Mediation analysis, categorical moderation analysis, and higher order constructs modeling in Partial Least Squares Structural Equation Modeling (PLSSEM): A B2B Example using SmartPLS. Marketing Bulletin, 26.

Yousef, D. A. (2001). Islamic work ethic - A moderator between organizational commitment and job satisfaction in a cross-cultural context. Personnel Review, 30(2), 152-169. https://doi.org/10.1108/00483480110380325

Zahrah, N., Norasyikin, S., Binti Abdul, S. H. B., Rani, A., Akmal, B., \& Mustafa, B. (2016). The relationship between Islamic religiosity, Islamic work ethics and job performance. In The European Proceedings of Social \& Behavioral Sciences (pp. 710-716). 